DETERMINATION OF TOTAL PHENOLIC COMPOUNDS AND EVALUATION OF THE ANTIOXIDANT ACTIVITY OF COMMERCIAL AND ARTISANAL GREEN TEA TRADED IN MARACAY, VENEZUELA

\section{DETERMINACIÓN DE COMPUESTOS FENÓLICOS TOTALES Y EVALUACIÓN DE LA ACTIVIDAD ANTIOXIDANTE DE TÉ VERDE COMERCIAL Y ARTESANAL COMERCIALIZADOS EN MARACAY, VENEZUELA}

Short report

Peer-reviewed

Franklin Pacheco-Coello*, María Peraza-Marrero, Corymar Orosco-Vargas, Doralys Ramirez-Azuaje, I bis Pinto-Catari

School of Health Sciences, Department of Basic Sciences, Laboratory of Chemistry and Instrumental Analysis, Laboratory of Heavy Metals and Organic Solvents, University of Carabobo, Postal Code 2103, phone +2446004000, Ruiz Pineda Street, La Morita II, Santa Rita Sector, Aragua State, Venezuela

Keywords: Polyphenols, Flavonoids, Infusions, FRAP, DPPH.

Palabras clave: Polifenoles, Flavonoides, Infusiones, FRAP, DPPH.

\begin{abstract}
Tea is considered one of the most consumed beverages in the world, due to its pleasant sensory properties, extensive health benefits and unique socio-cultural characteristics. The present study aimed to determine and compare the concentration of total phenolics, flavonoids and antioxidant capacity of green tea infusions. Two commercial brands of green tea and an artisanal or non-commercial green tea from China were used. Colorimetric methods were used for the determination of total and flavonoid and phenolics and the DPPH and FRAP methods for antioxidant activity. Of the three infusions, the highest concentration of total phenolics, flavonoids and antioxidant capacity was observed in the infusion of artisanal green tea from China, with a statistically significant difference $(p \leq 0.05)$. Its accessibility makes tea a good alternative for the consumption of substances with functional properties.
\end{abstract}

*Corresponding author: pachecofranklin74@gmail.com

\title{
RESUMEN
}

El té se considera una de las bebidas más consumidas en el mundo, debido a sus agradables propiedades sensoriales, amplios beneficios para la salud y características socioculturales únicas. El presente estudio tuvo como objetivo determinar y comparar la concentración de fenoles totales, flavonoides y capacidad antioxidante de las infusiones de 
té verde. Se emplearon dos marcas comerciales de té verde y un té verde artesanal o no comercial de China. Se utilizaron métodos colorimétricos para la determinación de fenoles totales y flavonoides y los métodos DPPH y FRAP para la actividad antioxidante. De las tres infusiones, la concentración más alta de fenoles totales, flavonoides y capacidad antioxidante se observó en la infusión de té verde artesanal de China, con una diferencia estadísticamente significativa $(\mathrm{p} \leq 0.05)$. Su accesibilidad hace del té una buena alternativa para el consumo de sustancias con propiedades funcionales.

\section{INTRODUCTION}

Tea is generally made from the leaves of Camellia sinensis, and is a very popular soft drink all over the world. Based on the fermentation degrees in an increasing order, tea can be classified into six categories, including green (unfermented), yellow (slight-fermented), white (mild-fermented), oolong (semi-fermented), black (deep-fermented), and dark (post-fermented) teas [1].

The consumption of tea has been correlated with low incidence of chronic pathologies, such as cardiovascular disease and cancer [2]. However, although the molecules involved in this effect have been shown to have antiinflammatory and antioxidant effects, and to improve endothelial function, no clear-cut conclusion has been reached on their mechanism of action [1]. The health benefits ascribed to the consumption of teas are thought to be associated with their high content of bioactive ingredients such as polyphenols. The latter are secondary plant metabolites and include the subclasses of flavonoids, flavones, flavonols, flavanols, isoflavones, flavanones, chalcones and anthocyanidins [3]. Within the polyphenols, the tea flavanols, catechins (flavan-3-ols) and theaflavins, have been identified as the bioactive phytochemicals of green tea and shown to be responsible for their antioxidant activity [4]. Apart from their antioxidant activity, tea flavanols could also have other activities of pharmacological interest [5,6], such as the ability to lower glucose, lipid and uric acid concentrations [7-9]. These activities could be mediated by their effects on various enzymes and transporters [8].

Knowing the various properties of tea, the present study aimed to make an analysis of the concentration of total phenolics, flavonoids and the antioxidant activity of the infusions of two brands of commercial teas and one artisanal from China.

\section{EXPERIMENTAL}

\section{Origin of plant material (PM)}

Two brands of green tea (PM) traded in Venezuela obtained from a super market in the city of Maracay $\left(10^{\circ} 14^{\prime} 49^{\prime \prime} \mathrm{N} 67^{\circ} 35^{\prime} 45^{\prime \prime} \mathrm{W}\right)$, and an original artisanal brand of green tea from China was used (Figure $\left.1 \mathrm{~A}, \mathrm{~B}, \mathrm{C}\right)$. The brands used were the following: Lipton (Brand 1), McCormick (Brand 2).

\section{Sample preparation for extraction}

2 grams of plant material were weighed. This was poured into a $400 \mathrm{~mL}$ Beaker, to which $200 \mathrm{~mL}$ of distilled water previously heated to the boiling point was added. The sample was slightly stirred for 4 min and filtered using Whatman No. 4 paper [10].

\section{Determination of total phenolics}

For the determination of total phenolics, $50 \mu \mathrm{L}$ were mixed with $250 \mu \mathrm{L}$ of the Folin-Ciocalteu $1 \mathrm{~N}$ reagent (Analytical grade, Merck). It was left to stand for 8 minutes and then $750 \mu \mathrm{L}$ of $20 \% \mathrm{Na}_{2} \mathrm{CO}_{3}$ and $950 \mu \mathrm{L}$ of distilled water were added.. Was incubated for $30 \mathrm{~min}$ at room temperature and the absorbance was read on a Genesis 20 UV/VIS spectrophotometer (Thermo Scientific, Waltham, Massachusetts, USA). A calibration curve for Gallic Acid (Sigma-Aldrich, Germany) was prepared with concentrations of 50, 100, 200, 300, 400, 500 and $1000 \mathrm{ppm}$. The results were expressed in mg of Gallic Acid Equivalents (GAE) / $g$ of PM [11].

\section{Determination of flavonoids}


ISSN 2078-3949 Rev, boliv, quim. Electronic edition

Franklin Pacheco coello et al. RBQ Vol. 37, No.1, pp. 28-33, 2020

A volume of $100 \mu \mathrm{L}$ of sample was mixed with $30 \mu \mathrm{L}$ of $5 \% \mathrm{w} / \mathrm{v} \mathrm{NaNO}, 30 \mu \mathrm{L}$ of $10 \% \mathrm{w} / \mathrm{v} \mathrm{AlCl}_{3}, 200 \mu \mathrm{L}$ of $1 \mathrm{M}$ $\mathrm{NaOH}$ and adjusted with distilled water to a final volume of $1 \mathrm{~mL}$. The reading was performed at $510 \mathrm{~nm}$ in a Genesis 20 UV / VIS spectrophotometer and was compared with a standard curve with standard (+)-catechin. The results were expressed in mg of Catechin Equivalents (CE) / g of PM [12].

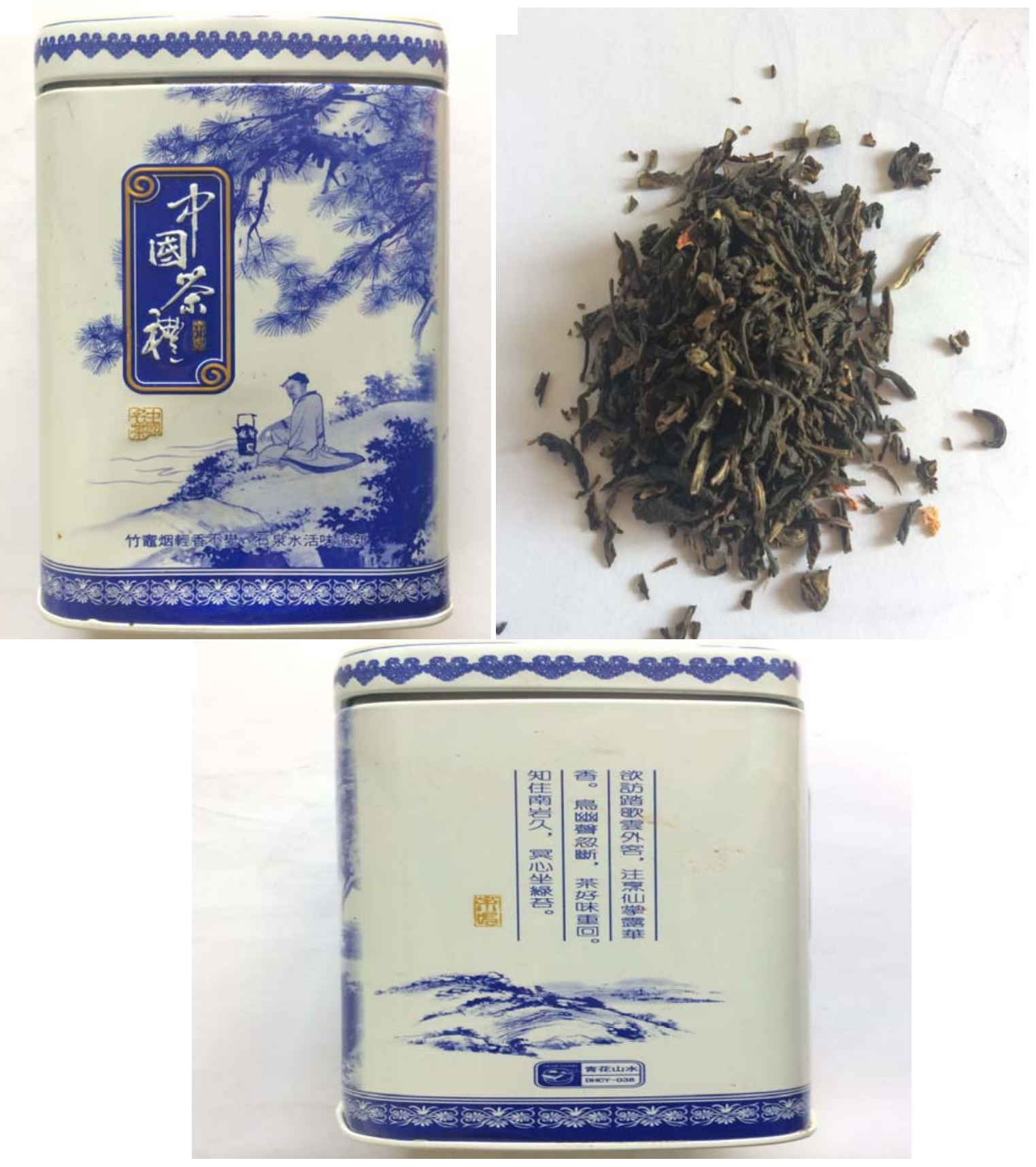

Figure 1. Artisanal green tea

Ferric-Reducing Antioxidant Power (FRAP) Assay 
The FRAP test was used to determine the reducing capacity of tea infusions [13]: $100 \mu \mathrm{L}$ of infusion were mixed with $3 \mathrm{~mL}$ of FRAP reagent consisting of a mixture of $300 \mathrm{mM}$ sodium acetate and acetic acid buffer, TPTZ solution (2,4,6-tri(2-pyridyl)-s-triazine) of $10 \mathrm{mM}$, and $20 \mathrm{mM} \mathrm{FeCl}_{3}$ solution, in a volume ratio of 10:1:1. The reaction was carried out at room temperature for $4 \mathrm{~min}$, and absorbance was recorded at $593 \mathrm{~nm}$ using a Genesis $20 \mathrm{UV} / \mathrm{VIS}$ spectrophotometer (Thermo Scientific, Waltham, Massachusetts, USA). $\mathrm{FeSO}_{4}$ was used as standard, and the results were expressed as $\mu \mathrm{mol} \mathrm{Fe}^{2+} / \mathrm{g} \mathrm{PM}$.

\section{Free radical 2,2-diphenyl-1-picrylhydrazyl (DPPH) Assay}

$100 \mu \mathrm{L}$ of sample and $2.9 \mathrm{~mL}$ DPPH (100 mM solution of DPPH in $80 \%$ methanol) (Sigma Aldrich) were placed together in a quartz cell. Absorbance (Genesis 20 UV/VIS spectrophotometer) was monitored every 5 min for 30 min at a wavelength of $515 \mathrm{~nm}$. The reference absorbance $\left(\mathrm{A}_{0}\right)$ was obtained by substituting the sample volume for $80 \%$ methanol. The percentage of DPPH reduction was obtained with the equation DPPH $(\%)=\left(A_{0}-A_{n}\right) 100 / A_{0}$, where $A_{0}$ and $A_{n}$ were the reference and sample absorbance, respectively [14]. The data were used to determine the $\mathrm{IC}_{50}$ parameter, which represents the concentration $\left(\mu \mathrm{g} \cdot \mathrm{mL}^{-1}\right)$ of phenolic compounds required to reduce the DPPH free radicals by $50 \%[15]$.

\section{Statistical analysis}

All determinations were made fivefold and the values were expressed as the means \pm the standard deviation. Statistical differences were determined by analysis of variance (ANOVA) by using the Statistic 9.0 program for Windows.

\section{RESULTS AND DISCUSSION}

\section{Total phenolics and flavonoids of the infusions}

Green tea showed the highest antioxidant capacity and total phenolic content, which could be due to the minimized oxidation degree of young leaves and the inactivated enzymes during the steaming process $[16,17]$.

The content of total phenolics and flavonoids was found to be higher in China's artisanal green tea leaves and lower in the mark 2 ( $\mathrm{p}=0.029$ and $\mathrm{p}=0.031$, respectively). There was no significant difference $(\mathrm{p} \geq 0.05)$ for both total and flavonoid phenolics between artisanal green tea from China and brand 1 . The mean and the standard deviation of the concentrations of teas are expressed in Table 1. The difference in the concentration of teas is related to that signaled by various studies which indicate that factors such as the way of cultivation, the place of production, planting conditions, harvest time, leaf quality and manufacturing process, determine the content of bioactive compounds and therefore their antioxidant capacity $[18,19]$.

Other studies indicate that the content of total phenolic compounds is variable in different types of green tea, in addition that the comparison with other studies is difficult because there are conditioning factors for the low or high yield of an infusion, whether commercial or not [20,21].

Table 1. Total phenolics (mg GAE / g MV) and flavonoids (mg CE / g MV).

\begin{tabular}{cccc}
\hline Bioactive Compounds & Brand 1 & Brand 2 & Artisanal \\
& $\mathbf{X} \pm$ DS & $\mathbf{X} \pm$ DS & $\mathbf{X} \pm$ DS \\
\hline Total phenolics & $201.34 \pm 3.98$ & $178.32 \pm 2.22$ & $220.10 \pm 2.20$ \\
Flavonoids & $118.32 \pm 2.09$ & $101.43 \pm 2.39$ & $140 \pm 1.95$ \\
\hline
\end{tabular}

\section{Antioxidant activity}

On the other hand, several studies mention that it is difficult to fully evaluate the antioxidant activities of natural tea compounds simply by using a single method of determination [22-24]. For the FRAP method, the statistical analysis showed an important difference between artisanal tea and green tea Brand $2(p=0.019)$. Of the $\mathrm{IC}_{50}$ obtained (concentration in $\mu \mathrm{g} . \mathrm{mL}^{-1}$ of phenolic compounds required to reduce $50 \%$ of the free DPPH radical) of 
teas infusions, a greater antioxidant power was observed in the infusion of artisanal tea, with statistical difference when compared with the brand $2(\mathrm{p}=0.028$, Table 2$)$.

Although the results of the teas were different, no statistical difference was observed between the brand 1 and the artisanal one, possibly due to the fact that the green tea leaves of that brand come from Sri Lanka, one of the countries with the highest production of green tea in the world.

Table 2. Antioxidant activity of infusions

\begin{tabular}{ccc}
\hline Plant Material & FRAP & DPPH \\
& $\mathrm{Fe}^{+2} / \mathrm{g} \mathrm{MP}$ & $\mu \mathrm{g}_{\mathrm{m}} \mathrm{mL}^{-1}$ \\
& $\mathrm{X} \pm \mathrm{DS}$ & $\mathrm{X} \pm \mathrm{DS}$ \\
\hline Brand 1 & $4110.80 \pm 1.11$ & $180.30 \pm 1.04$ \\
Brand 2 & $2172.80 \pm 2.12$ & $220.30 \pm 2.04$ \\
Artisanal & $4180.80 \pm 2.17$ & $160.30 \pm 2.04$
\end{tabular}

In a study conducted by researchers of the University of Shanghai, it's reported that the 30 infusions of green tea from different regions of China had a high antioxidant power and were rich in phenolic compounds, varying from one region to another. The authors pointed out that tea is a good dietary source of natural antioxidants, especially phenolic compounds that have a good potential to become a functional beverage [25].

\section{CONCLUSIONS}

There are differences in the content of bioactive compounds and their antioxidant activity between the Chinese artisanal tea and the brand 2, currently traded in Venezuela, with a more important antioxidant activity in the artisanal sample. All three tea varieties studied herein are excellent alternatives for the consumption of bioactive compounds, with great health benefits.

\section{REFERENCES}

1. Hashimoto, T., Goto, M., Sakakibara, H., Oi, N., Okamoto, M. 2007. Yellow tea is more potent than other types of tea in suppressing liver toxicity induced by carbon tetrachloride in rats, Phytother Research 21, 668-670.

2. Tang, J, Zhen, J.S., Fan, L., Jin, Y., Cai, W. 2015, Tea consumption and mortality of all cancers, CVD and all causes: a metaanalysis of eighteen prospective cohort studies, British Journal of Nutrition, 114(1), 673-683.

3. Del Rio, D., Rodríguez-Mateos, A., Spencer, J., Tognolini, M., Borges, G., Crozier, A. 2013, Dietary (poly)phenolics in human health: structures, bioavailability, and evidence of protective effects against chronic diseases, Antioxidants Redox Signaling, 18(1), 1818-1892.

4. Di Lorenzo, A., Nabavi, S.F., Sureda, A.,. Moghaddam, A.H., Khanjani, S., Arcidiaco, P., Nabavi, S.M., Daglia, M. 2016, Antidepressive-like e_ects and antioxidant activity of green tea and GABA green tea in a mouse model of post-stroke depression, Molecular Nutrition \& Food Research, 60, 566-579.

5. Liu, K., Zhou, R., Wang, B., Chen, K., Shi, L.Y., Zhu, J.D. 2013, Effect of green tea on glucose control and insulin sensitivity: a meta-analysis of 17 randomized controlled trials, American Journal of Clinical Nutrition, 98,340-348.

6. Zheng, X.X., Xu, Y.L., Li, S.H., Liu, X.X., Hui, R., Huang XH. 2013, Effects of green tea catechins with or without caffeine on glycemic control in adults: a meta-analysis of randomized controlled trials, American Journal of Clinical Nutrition, 97(1), 750-762

7. Onakpoya, I., Spencer, E., Heneghan, C., Thompson, M. 2014, The effect of green tea on blood pressure and lipid profile: a systematic review and meta-analysis of randomized clinical trials, Nutrition, Metabolism \& Cardiovascular, 24, 823-836.

8. Peluso, I., Teichner, A., Manafikhi, H., Palmery, M. 2015, Camellia sinensis in asymptomatic hyperuricaemia: a meta-analysis of tea or tea extract effects on uric acid levels, Critical Reviews in Food Science and Nutrition, 23(4), 143-155.

9. Kim, Y.H., Won, Y.S., Yang, X., Kumazoe, M., Yamashita, S., Hara, A., Takagaki, A., Goto, K., Nanjo, F., Tachibana, H. 2016, Green tea catechin metabolites exert immunoregulatory effects on $\mathrm{CD}^{4+} \mathrm{T}$ cell and natural killer cell activities, Journal of Agricultural and Food Chemistry, 64, 3591-3597.

10. Horžić, D., Komes, D., Belščak, A., Kovačević, K., Iveković, D., Karlović, D. 2009, The composition of polyphenolics and methylxanthines in teas and herbal infusions, Food Chemistry, 115, 441-448.

11. Ayala-Zavala, JF., Silva-Espinoza, A.B., Cruz-Valenzuela, R.M., Villegas-Ochoa, M.A. 2013, Antioxidant and antifungal potential of metanol extracts of Phenillus sp, Revista Iberoaméricana de Micolología, 29(3), 132-138.

12. Marinova, D., Ribarova, F., Atanassova, M. 2005, Total phenolics and total flavonoids in bulgarian fruits and vegetables, Journal of the University of Chemical Technology and Metallurgy, 40(3), 255-260.

13. Benzie, I.F.F., Strain, J.J. 1996, The ferric reducing ability of plasma (FRAP) as a measure of "Antioxidant power": The FRAP assay, Analytical Biochemistry,239, 70-76.

Downloadable from: Revista Boliviana 32 de Química. Volumen $37 \mathrm{~N}^{\circ} 1$. Año 2020

http://www.bolivianchemistryjournal.org, http://www.scribd.com/bolivianjournalofchemistry 
Franklin Pacheco Coello et al. RBQ Vol. 37, No.1, pp. 28-33, 2020

14. Soler-Rivas, C., Espín, J.C., Wichers, H.J. 2000, An easy and fast test to compare total free radical scavenger capacity of foodstuffs, Phytochemical Analysis, 11(2), 330-338.

15. Einbond, S.L., Reynertson, A.K., Xiao-Dong, L., Fing, Y.U. 2004, Anthocyanin antioxidants from edible fruits, Food Chemistry, $84(1), 23-28$.

16. Lin Y.S., Tsai, Y.J., Tsay, J.S., Lin, J.K., Siah, L.U. 2003, Factors affecting the levels of tea polyphenolics and caffeine in tea leaves, Journal of Agricultural and Food Chemistry, 51, 1864-1873.

17. Scoparo, C.T., De Souza, L.M., Rattmann, Y.D., Kiatkoski, E.C., Dartora, N., Iacomini, M. 2016, The protective effect of green and black teas (Camellia sinensis) and their identified compounds against murine sepsis, Food Research International, 83, 102111.

18. Bi, W., He, C.N., Ma, Y.Y., Shen, J., Zhang, L.H. 2016, Investigation of free amino acid, total phenolics, antioxidant activity and purine alkaloids to assess the health properties of non-Camellia tea, Acta Pharmaceutica Sinica, 6, 170-181.

19. Raudonis, R., Raudone, L., Jakstas, V., anulis. V. 2012, Comparative evaluation of post-column free radical scavenging and ferric reducing antioxidant power assays for screening of antioxidants in strawberries, Journal of Chromatography,123 (3), 8-15.

20. De Feria F. Tesis de grado, Characterization of phenolic composition and antioxidant capacity of different tea brands (Camellia sinensis) traded in Chile, Pontificia Universidad Católica de Chile, Santiago, Chile, 2011.

21. Hartley, L., Flowers, N., Holmes, J., Clarke, A., Stranges S., Hooper, L. 2013, Green and black tea for the primary prevention of cardiovascular disease, Cochrane Database of Systematic Reviews, 18(6), 324-335.

22. Higdon, J.V., Frei, B. 2003, Tea catechins and polyphenolics: Health effects, metabolism, and antioxidant functions, Food Science, 43, 89-143.

23. Liu, Q., Tang, G.Y., Zhao, C.N., Liu, F.A., Siu, Y.U. 2019, Antioxidant activities, phenolic profiles, and organic acid contents of fruit vinegars, Antioxidants, 8(6),8-78.

24. Xu, D.P., Li, Y., Meng, X., Tang, Y.U. 2017, Natural antioxidants in foods and medicinal plants: Extraction, assessmentandresources, Journal of Molecular Sciences, 18(3),118-124.

25. Zhao, C.N., Tang, G.Y., Cao, S.Y. 2019, Phenolic Profiles and Antioxidant Activities of 30 Tea Infusions from Green, Black, Oolong, White, Yellow and Dark Teas, Antioxidants, 8(7), 200-215. 